\title{
Електронно-мікроскопічні зміни ацинарних відділів привушної слинної залози при механічній жовтяниці
}

\author{
M. O. LEVKIV, A. H. SHULHAY \\ SHEI "Ternopil State Medical Uversity by I. Ya. Horbachevsky"
}

\section{ELECTRON MICROSCOPIC CHANGES OF ACINAR PARTS OF PAROTID SALIVARY GLAND INTHE COURSE OF OBSTRUCTIVEJAUNDICE}

\begin{abstract}
У статті наведено дані ультраструктурних змін ацинарних відділів та капілярного русла привушної слинної залози при різних термінах механічної жовтяниці. Встановлено, що тривалий холестаз призводить до дистрофічних та деструктивних змін у структурах секреторних клітин, що виражено знижує їх функціональний стан, а іноді призводить до загибелі клітини.

The article presents data of ultrastructural changes of acinar parts and capillary bed of parotid salivary gland during different periods of obstructive jaundice. It was found out that prolonged cholestasis leads to degenerative and destructive changes in the structures of the secretory cells, thus obviously reduce their functional state, and sometimes leads to cell death.
\end{abstract}

Постановка проблеми і аналіз останніх досліджень та публікацій. Серед різних форм патології біліарної системи найбільш тяжку групу складають хворі з механічною жовтяницею. Синдром обтураційної жовтяниці об'єднує досить широке коло захворювань, загальною ознакою яких $€$ виникнення непрохідності магістральних жовчних проток. Вона характеризується виникненням різних тяжких ускладнень, що визначають, якщо своєчасно не відновити відтік жовчі, загальний прогноз захворювання [2]. Дослідженнями багатьох вчених встановлено функціональні та структурні зміни в органах травного тракту при різній тривалості механічної жовтяниці. Враховуючи загальний холемічний фактор та високу чутливість слинних залоз до різноманітних екзогенних та ендогенних впливів, у привушній залозі настають різного роду реактивні зміни, які полягають у зміні функціонального та структурного стану органа $[1$, 3]. Важливим $€$ і те, що при механічній жовтяниці настають судинні розлади, які характеризуються вираженими порушеннями кровообігу, проникності судинної стінки, що в комплексі із гідрофільними реакціями призводить до утворення периваскулярних лімфоїдно-клітинних інфільтратів, наслідком яких $\epsilon$ дегенеративно-дистрофічні й некротичні зміни тканин вогнищевого типу, запальні реакції 3 розвитком продуктивних інтерстиціальних процесів [4]. Внаслідок холемії та ендогенної інтоксикації, порушення вільнорадикальних процесів окиснення зростає кількість альтеративних факторів, які мають пряму пошкоджувальну дію на ендотеліальні клітини, що зумовлює підвищення проникності капілярів [5]. При цьому важливим $\epsilon$ дослідження не тільки біохімічних та морфологічних ознак змін, які лежать в основі патогенезу ураження слинних залоз при механічній жовтяниці, але й ознаки ураження ацинарних клітин та ендотелію мікросудин обмінного рівня на клітинному рівні. Серед існуючих досліджень привушної залози при захворюваннях печінки та жовчних шляхів недостатньо висвітлено питання ультраструктурних змін сероцитів привушної слинної залози при різних термінах обтураційного холестазу, не встановлено кореляційних зв'язків між глибиною ураження секреторних клітин та структурним і функціональним станом клітин капілярного русла.

Мета роботи: встановити субмікроскопічні зміни в ацинарних відділах та капілярах привушної слинної залози при різних термінах механічної жовтяниці.

Матеріали і методи. Експериментальні дослідження проведено на 36 білих щурах-самцях. Кон- 
трольну групу склали 12 інтактних тварин. Механічну жовтяницю моделювали шляхом перев'язування та перерізання між двома лігатурами спільної жовчної протоки. Дослідження привушної залози проводили на 7-му та 28-му добу експериментальної механічної жовтяниці. Евтаназію щурів здійснювали шляхом введення великих доз $10 \%$ розчину тіопенталу натрію. Усі втручання проводили з дотриманням принципів Свропейської конвенції про захист хребетних тварин, які використовуються для експериментальних та наукових цілей (Страсбург, $1985)$ та ухвали Першого національного конгресу 3 біоетики (Київ, 2001). Для ультраструктурних досліджень вирізали маленькі шматочки привушної слинної залози. Матеріал фіксували у 2,5 \% розчині глютаральдегіду, постфіксували 1 \% розчином тетроксиду осмію на фосфатному буфері, зневоднювали в спиртах і ацетоні та заливали в суміш аралдиту з епоксидними смолами. Ультратонкі зрізи, виготовлені на ультрамікротомі LKB-3, контрастували ураніл ацетатом та цитратом свинцю за методом Рейнольдса і вивчали під електронним мікроскопом ПЕМ-125К.

Результати досліджень та їх обговорення. При електронно-мікроскопічному дослідженні тканини привушної слинної залози на 7-му та 28-му добу обтураційної жовтяниці було встановлено значні зміни ультраструктури секреторних відділів. Процеси ремоделювання торкнулися всіх складових елементів часточок: епітеліальних комплексів, сполучнотканинних компонентів і обмінних мікросудин. Так, проведеними субмікроскопічними дослідженнями на 7-му добу обтураційного холестазу встановлено зростання явищ гідратації та дисциркуляторних порушень. Особливо це помітно в системі мікросудин. При цьому в багатьох випадках кровоносні капіляри були виповнені еритроцитами 3 ознаками сладж-феномену (рис. 1). В ендотеліальних клітинах цитоплазма в ділянці перикаріону невисокої електронної щільності, містила невелику кількість мітохондрій, багато цитогранул і міхурців, а також канальці цитоплазматичної сітки. Більшість мітохондрій була $з$ дистрофічними змінами у вигляді вогнищевої дискомплексації крист. Пластинчастий комплекс представлений цистернами із гладкоконтурних мембранних профілів. Ядра клітин із нечітким розділенням еу- і гетерохроматину. Каріоплазма потовщена, слабоосміофільна. В окремих ендотеліальних клітинах на люмінальній поверхні зустрічалися короткі, різної товщини мікроворсинки з ознаками їх мікроклазматозу.

У цитоплазмі таких клітин знаходили органели у деструктивному стані. Зміни базальної мембра-

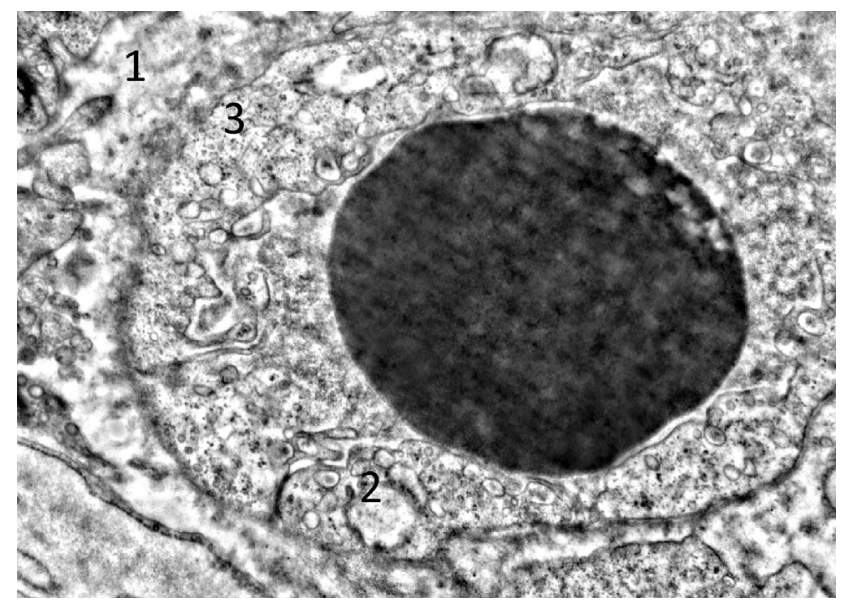

Рис. 1. Ультраструктура гемокапіляра привушної слинної залози на 7-му добу механічної жовтяниці. Набряк та розширення перикапілярного простору (1), деструкція крист мітохондрій (2), набряк цитоплазми та розширення канальців ендоплазматичного ретикулуму (3). $\times 7000$.

ни мали вогнищевий характер і торкалися окремих ділянок кровоносного капіляра. Перикапілярні простори виражено розширювалися. У внутрішньочасточковій сполучній тканині спостерігали ознаки підвищеної гідратації. При цьому зменшувалася оптична щільність основної речовини, розширювалися міжацинарні зв'язки та вузлові інтерстиційні щілини. Спостерігали дезорганізацію фібрилярної сітки, яка оточує кінцеві відділи і протокову систему привушної слинної залози. Кількість фібрил і їх архітектоніка не однакові в різних відділах. Переплітаючись між собою, вони формували над поверхнею ацинуса певного виду пучки.

В апікальних відділах сероцитів виявляли гранули середньої та низької електронної щільності. Цитоплазматичний матрикс містив збільшену кількість вакуолей. У мітохондріях були пошкодженими кристи, у багатьох випадках недостатньо візуалізувалася зовнішня мембрана. Канальці ендоплазматичної сітки мали переважно базальне розташування та розширювалися (рис. 2). Вони містили матеріал помірної електронної щільності.

На поверхні канальців виявляли невелику кількість мембранозв'язаних рибосом. Цистерни комплексу Гольджі розширювалися та зменшували кількість периферійно розташованого осміофільного матеріалу. Апікальні поверхні плазмолеми утворювали випинання та мікроворсинки, які були різними за розмірами, часто деструктивно зміненими. Міжклітинні щілини добре візуалізувалися, мали нерівний хід за рахунок дрібних розширень протягом всієї довжини, іноді до базальної мембрани. У деяких кінцевих відділах визначались цистерноподібні розширення міжклітинних щілин, які 


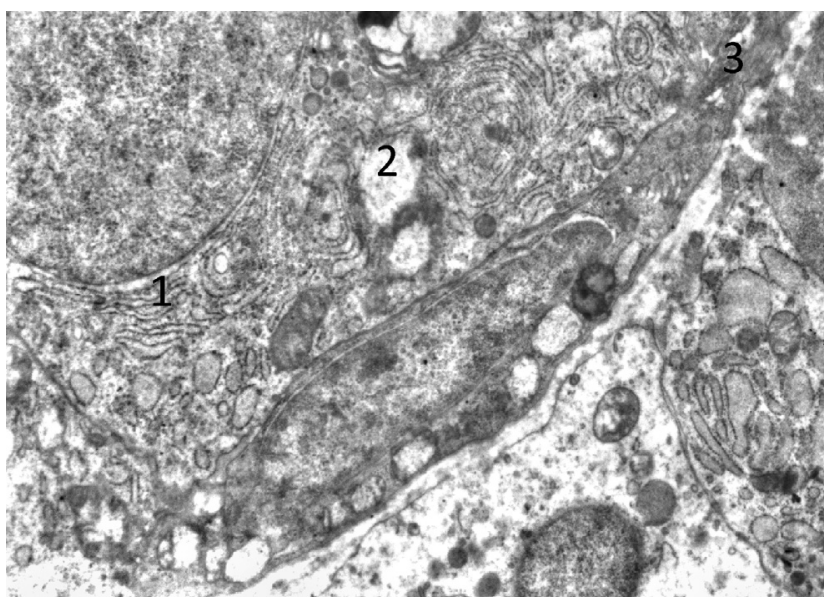

Рис. 2. Ультраструктура сероцита при тижневій обтураційній жовтяниці. Базально розташовані розширені канальці ендоплазматичної сітки (1), мітохондрії зі зруйнованими кристами та оболонками (2), набрякла цитоплазма міоепітеліальної клітини (3). ×8000.

сполучалися з просвітами кінцевих відділів, на відміну від контрольної групи, де вони були вузькими, з невеликою кількістю складок бічних плазмолем. Навколоядерні простори розширювалися. У ядерній оболонці виявляли поодинокі пори. У самих ядрах збільшувалася кількість неконденсованого хроматину. Базальні відділи сероцитів охоплювали міоепітеліальні клітини, які в більшості випадків разом із ацинарними клітинами розташовувалися на спільній базальній мембрані. Характерним для міоепітеліальних клітин у тижневий термін обтураційного холестазу було стоншення їхніх периферичних відростків та зменшення у них мікрофіламентів. У цитоплазмі збільшувалася кількість піноцитозних міхурців (рис. 3). Отже, такий стан

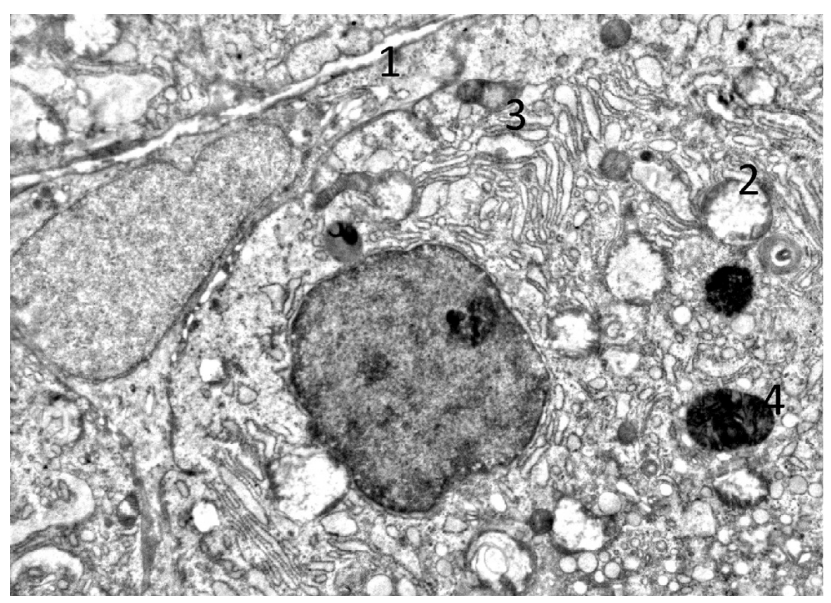

Рис. 3. Субмікроскопічні зміни ацинуса привушної слинної залози на 7-му добу обтураційного холестазу. Відросток міоепітеліальної клітини (1), секреторні гранули низької (2), середньої (3) та високої (4) електронної щільності. $\times 7000$. клітин та капілярного русла ацинарних відділів привушної слинної залози свідчить про наявність дисциркуляторних порушень, які супроводжуються дистрофічними та деструктивними процесами.

У цитоплазмі епітеліоцитів вставних відділів електронно-мікроскопічно добре контурувалися тонофібрили та поодинокі полісоми. На апікальній поверхні цих клітин містилися різних розмірів мікроворсинки, з ознаками дискомплексації а деякі фрагментації. Бокові контакти епітеліоцитів розширювалися, іноді вони у базальних відділах виявлялися значними. Ядра таких клітин зберігали округло-овальну форму. Відзначено зміни каріолеми. Перинуклеарні простори розширюються за рахунок відшарування зовнішньої ядерної мембрани. Кількість ядерних пор визначалася невеликою. У цитоплазмі були деструктивно зміненими органели. Мітохондрії у більшості випадків мали зруйновані кристи та осміофільний гомогенізований матрикс. У багатьох епітеліоцитів канальні ендоплазматичної сітки та цистерни комплексу Гольджі були потовщеними, а іноді утворювали вакуолі. Зовні епітеліоцити вставних проток охоплені міоепітеліальними клітинами.

При місячному обтураційному холестазі ультраструктурне дослідження судинних стінок виявляло дезорганізацію структур у клітинах усіх оболонок. Ендотеліальні клітини були дистрофічно зміненими (рис. 4), з розширеними канальцями ендоплазматичної сітки, просвітленим матриксом мітохондрій і зруйнованими кристами. Частина ендотеліальних клітин відрізнялася зменшенням кількості вільних рибосом. Ядра утворювали багато поверхневих і глибоких інвагінацій. Перинукле-

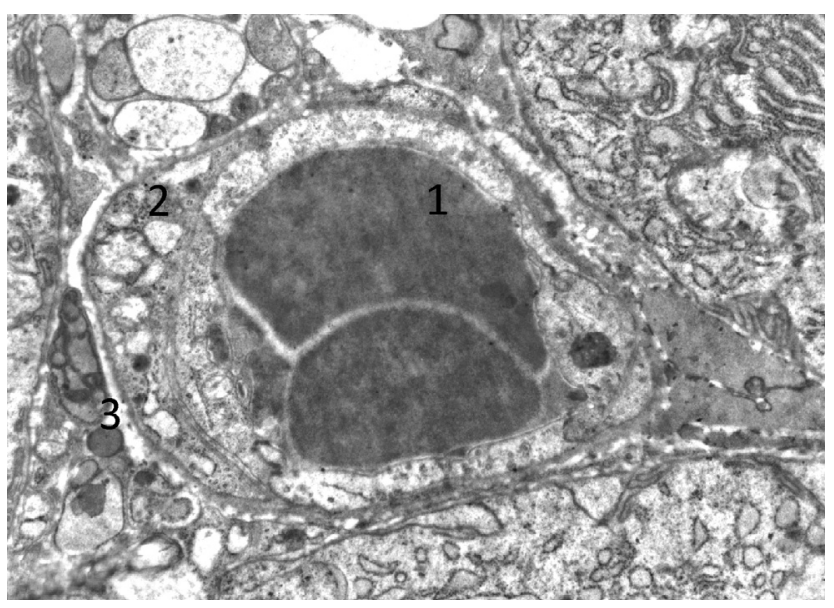

Рис. 4. Ультраструктура гемокапіляра привушної слинної залози при місячній механічній жовтяниці. Просвіт капіляра виповнений еритроцитами з ознаками “сладж-феномену” (1), деструктивно змінена ендотеліальна клітина в стадії загибелі (2), розширений перикапілярний простір (3). ×7000. 
арні простори були розширеними. Люмінальна поверхня ендотеліоцитів формувала різної товщини мікроворсинки з ознаками їх мікроклазматозу. Пластинчастий комплекс представлений цистернами із гладкоконтурних мембранних профілів. У складі його везикулярного компонента зустрічалися міхурці дрібних розмірів. В окремих ендотеліоцитах виявляли ліпосоми і первинні лізосоми. Базальна мембрана багатьох капілярів була розволокнена, часто пошкоджена або погано контурувалася, перикапілярні простори виражено розширені із підвищеною кількістю колагенових волокон.

При цьому відбувалися процеси колагенізації міжацинарних проміжків та перидуктальних просторів. Фібрили тонкої філаментної сітки, яка огортала ацинуси та вивідні протоки, змінювала сполучна тканина, внаслідок чого зникав епітеліально-мезенхімальний зв'язок.

При дослідженні ацинарних відділів встановлено, що у сероцитах ацинусів відбувалися характерні процеси, які вказували на порушення синтезу та виділення секрету, зміни зі сторони ядра та плазмолеми. У мітохондріях просвітлений матрикс, більшість крист зруйновані та фрагментовані. Цистерни ендоплазматичної сітки формували вакуолі, часто були з ознаками деструктивних змін. Апарат Гольджі представлений дискомплексованими формами складових (рис. 5). Такі дані білоксинтезуючих субклітинних структур вказували на зменшення та порушення іï синтезуючої активності.

При цьому в епітеліоцитах вставних внутрішньочасточкових проток відбувалися деструктивноатрофічні процеси, що вказували на виражене зниження їхньої функціональної активності. Каріолема ядер клітин була нерівною, утворювала інвагінації.

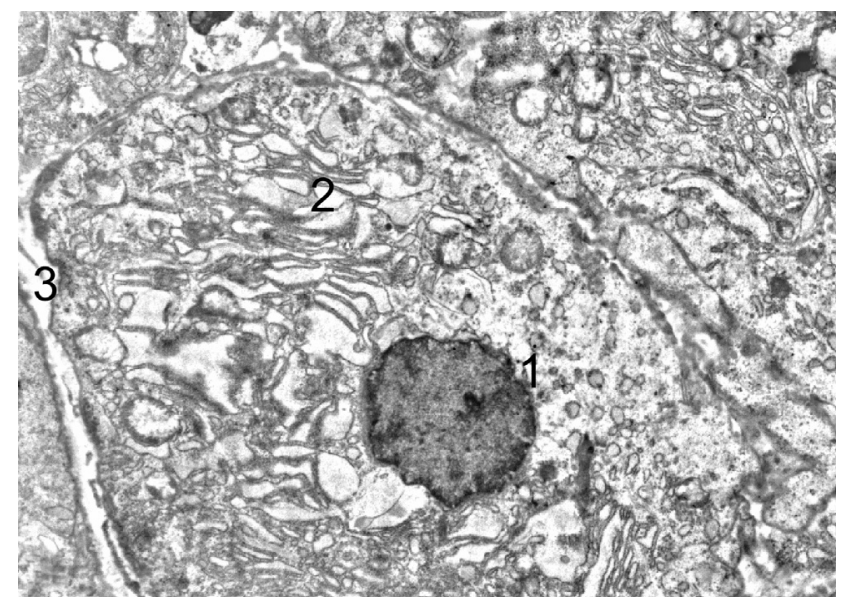

Рис. 5. Ультраструктурні зміни сероцитів на 28-му добу механічної жовтяниці. Інвагінації каріолеми (1), накопичення незрілих секреторних гранул в апікальних відділах (2), розширення міжклітинних проміжків (3).×7000.
Гетерохроматин осміофільними ділянками розташовувався вздовж каріолеми та утворював грудки у каріоплазмі. У цитоплазмі зменшеною була кількість пластинчастих тілець та цистерн ендоплазматичної сітки. Кількість мітохондрій значно зменшена, вони деструктивно змінені. У цитоплазмі зустрічалися неправильної форми світлі структури. Часто між латеральними поверхнями протокових епітеліоцитів визначались лімфоцити на різній відстані від базальної мембрани.

Такий стан свідчить про зменшення функціональної активності протокового епітелію та атрофічні процеси стінок вивідних проток.

Відомо, що привушна слинна залоза $є$ складним секреторним органом, який виконує різноманітні функції та має велике значення для життєдіяльності організму людини. Морфофункціональні зміни тканин привушної залози при механічній жовтяниці безпосередньо пов'язані із процесами холемії, ендогенної інтоксикації і цитотоксичних впливів жовчних кислот та вільнорадикальних процесів окиснення на клітини кровоносних капілярів, секреторних і видільних відділів.

Провідними патогенетичними проявами при цьому виступають морфологічні зміни на рівні внутрішньої оболонки судин обмінного рівня, ацинарних сероцитів та епітелію вставних внутрішньочасточкових проток, які характеризувалися набряком та ознаками деструктивних змін органел. Серед епітеліоцитів вивідних проток пошкоджувалися міжклітинні десмосомальні та пальцеві контакти, в яких знаходили міжепітеліальні лімфоцити. Ці види міжклітинних контактів відіграють ключову роль у координації клітинної організації епітеліоцитів і в передачі інформації до клітини [1]. Роз'єднання міжклітинних контактів та порушення їх взаємодії приводить до пошкодження складних мембранозв'язаних рецепторних систем [3].

Структурні зміни ендотеліоцитів капілярів, а також базальної мембрани супроводжувалися колагенізацією перикапілярних просторів. Збільшена ємність судин обмінного рівня не була достатньою для зменшення гіпоксичного стану, який, крім того, ще й підтримувався мітохондріальними дисфункціями в епітеліоцитах та гландулоцитах. Результатом набряково-гіпоксичних процесів стало розширення інтерстиційних міжацинарних, периваскулярних та перидуктальних просторів. Причому заміщення фібрилярного комплексу сполучною тканиною негативно впливає на формування гідростатичного тиску та переміщення рідини з інтерстиціального простору в систему вивідних проток. Деструктивні процеси органел цитоплазми та дистрофічні, а в деяких випадках деструктивні зміни 
ядер у сероцитах призводять до вираженого зменшення секреторних здатностей клітини, що безпосередньо впливає на її функціональну діяльність, а часто супроводжується некрозом або апоптозом. При цьому виражені деструктивні процеси ядра та оранел цитоплазми призводять до загибелі гландулоцитів та епітеліоцитів вставних вивідних проток.

Висновки. Результати проведених досліджень дозволяють вважати, що в основі патогенезу сіалоаденіту привушних слинних залоз при механічній жовтяниці провідна роль належить порушенням кро-

\section{СПИСОК ЛІТЕРАТУРИ}

1. Срошенко Г. А. Зміни структури привушної залози щурів після введення адреналіну і ацетилхоліну / Г. А. Срошенко // Український журнал клінічної та лабораторної медицини. Луганськ, 2008. - Т. 3, № 3. - С. 39-45.

2. Шульгай А. Г. Морфометричні особливості ремоделювання структур привушної слинної залози при механічній жовтяниці / А. Г. Шульгай, М. О. Левків // Шпитальна хірургія. 2012. - Т. 57, № 1. - С. 39-43.

3. Ярославська Ю. Ю. Морфопатогенетичні ознаки у хворих вообігу на рівні судин обмінного рівня та цитотоксичним впливам холемії на секреторні ацинарні клітини. Причому тривалий холестаз приводить до дистрофічних та деструктивних змін у структурах секреторних клітин, що виражено знижує їхній функціональний стан, а іноді призводить до загибелі клітини.

Перспективи подальших досліджень. Розкриття патогенезу морфологічних змін привушної слинної залози при механічній жовтяниці дозволить розробити методи своєчасного лікування і попередження структурних і функціональних зрушень.

на хронічний сіалоаденіт із сіалолітіазом / Ю. Ю. Ярославська // Український стоматологічний альманах. - 2005. - № 2. C. $16-21$.

4. Perez M. J. Bile-acid-induced cell injury and protection / M. J. Perez, O. Briz // World J. Gastroenterol. - 2009. - Vol. 14, № 15. - P. 1677-1689.

5. Tiao M. M. The role of mitochondria in cholestatic liver injury / M. M. Tiao // Chang Gung Med. J. - 2009. - Vol. 32, № 4. P. 346-353.

Отримано 03.01.13 